ҚАЗАҚСТАН РЕСПУБЛИКАСЫ

ҰЛТТЫҚ ҒЫЛЫМ АКАДЕМИЯСЫНЫН

АБАЙ АТЫНДАҒЫ ҚАЗАҚ ҰЛТТЫҚ

ПЕДАГОГИКАЛЫҚ УНИВЕРСИТЕТІНІҢ

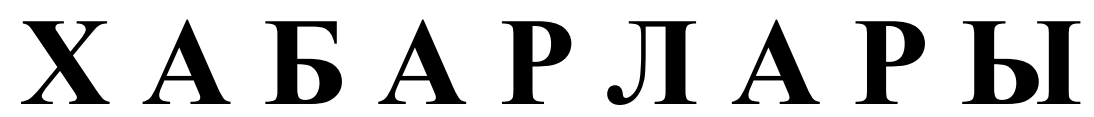

\section{ИЗВЕСТИЯ}

НАЦИОНАЛЬНОЙ АКАДЕМИИ НАУК РЕСПУБЛИКИ КАЗАХСТАН

КАЗАХСКИЙ НАЦИОНАЛЬНЫЙ

ПЕДАГОГИЧЕСКИЙ УНИВЕРСИТЕТ ИМ. АБАЯ

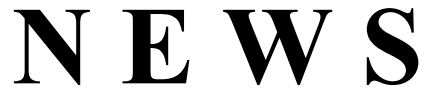

OF THE NATIONAL ACADEMY OF SCIENCES OF THE REPUBLIC OF KAZAKHSTAN

ABAY KAZAKH NATIONAL PEDAGOGICAL UNIVERSITY

ҚОҒАМДЫҚ ЖӘНЕ ГУМАНИТАРЛЫҚ ҒЫЛЫМДАР СЕРИЯСЫ

СЕРИЯ ОБЩЕСТВЕННЫХ И ГУМАНИТАРНЫХ НАУК

$\checkmark$

SERIES OF SOCIAL AND HUMAN SCIENCES

$$
5 \text { (321) }
$$

КЫРКУЙЕК - КАЗАН 2018 ж.

СЕНТЯБРЬ - ОКТЯБРЬ 2018 Г.

SEPTEMBER - OCTOBER 2018

1962 ЖЫЛДЫҢ ҚАНТАР АЙЫНАН ШЫҒА БАСТАҒАН

ИЗДАЕТСЯ С ЯНВАРЯ 1962 ГОДА

PUBLISHED SINCE JANUARY 1962

ЖЫЛЫНА 6 РЕТ ШЫҒАДЫ

ВЫХОДИТ 6 РАЗ В ГОД

PUBLISHED 6 TIMES A YEAR 
Ба с ре дактор

ҚР ҰҒА кұрметті мүшесі

Балықбаев Т.O.

Р е д а ц и я а лқ а сы:

экон. ғ. докторы, проф., ҚР ҰҒА академигі Баймұратов У.Б.; тарих ғ. докторы, проф., ҚР ҰҒА академигі Байпақов К.М.; филос. ғ.докторы, проф., ҚР ҰҒА академигі Есім Г.Е.; фил. ғ. докторы,, проф., ҚР ҰҒА академигі Қирабаев С.С.; эк. ғ. докторы, проф., ҚР ҰҒА академигі Кошанов А.К.; эк.ғ. докторы, проф., ҚР ҰҒА академигі Нәрібаев К.Н. (бас редактордың орынбасары); филос. ғ.докторы, проф., ҚР ҰҒА академигі Нысанбаев А.Н.; заң ғ. докторы, проф., ҚР ҰҒА академигі Сәбікенов С.Н.; заң ғ. докторы, проф., ҚР ҰҒА академигі Сүлейменов М.К.; эк. ғ. докторы, проф., ҚР ҰҒА академигі Сатыбалдин С.С.; тарих ғ. докторы, проф., ҚР ҰҒА академик Әбжанов Х.М.; тарих ғ. докторы, проф., ҚР ҰҒА корр. мүшесі Әбусеитова М.Х.; тарих ғ. докторы, проф., ҚР ҰҒА академик Байтанаев Б.А.; филол. ғ. докторы, проф., ҚР ҰҒА корр. мүшесі Жақып Б.А.; фил. ғ. докторы, проф., академик НАН РК Қалижанов У.К.; филол. ғ. докторы, проф., ҚР ҰҒА академик Қамзабекұлы Д.; тарих ғ. докторы, проф., ҚР ҰҒА академик Қожамжарова Д.П.; тарих ғ. докторы, проф., ҚР ҰҒА академик Койгелдиев М.К.; фил. ғ. докторы, проф., ҚР ҰҒА корр. мүшесі Кұрманбайұлы Ш.; тарих ғ. докторы, проф., ҚР ҰҒА корр. мүшесі Таймағанбетов Ж.К.; социол. ғ. докторы, проф., ҚР ҰҒА корр. мүшесі Шәукенова 3.К.; фил. ғ. докторы, проф., КР ҰҒА корр. мүшесі Дербісәлі А.; саяси. ғ. докторы, проф., Бижанов А.К., тарих ғ. докторы, проф., Кабульдинов 3.Е.; фил. ғ. докторы, проф., ҚР ҰҒА корр мүшесі Қажыбек Е.3.

\section{Р едакция ке н е с i:}

Молдова Республикасының ҰҒА академигі Белостечник Г. (Молдова); Әзірбайжан ҰҒА академигі Велиханлы Н. (Азербайджан); Тәжікстан ҰҒА академигі Назаров Т.Н. (Тәжікстан); Молдова Республикасының ҰҒА академигі Рошка А. (Молдова); Молдова Республикасының ҰҒА академигі Руснак Г. (Молдова); Әзірбайжан ҰҒА корр. мүшесі Мурадов Ш. (Әзірбайжан); Әзірбайжан ҰҒА корр. мүшесі Сафарова 3. (Әзірбайжан); э. ғ. д., проф. Василенко В.Н. (Украина); заң ғ. докт., проф. Устименко В.А. (Украина)

«Қазақстан Республикасы Ұлттық ғылым академиясының Хабарлары. Қоғамдық және гуманитарлық ғылымдар сериясы». ISSN 2224-5294

Меншіктенуші: «Қазақстан Республикасының Ұлттық ғылым академиясы» РҚБ (Алматы қ.)

Қазақстан республикасының Мәдениет пен ақпарат министрлігінің Ақпарат және мұрағат комитетінде 30.04.2010 ж. берілген № 10894-Ж мерзімдік басылым тіркеуіне қойылу туралы куәлік

Мерзімділігі: жылына 6 рет.

Тиражы: 500 дана.

Редакцияның мекенжайы: 050010, Алматы қ., Шевченко көш., 28, 219 бөл., 220, тел.: 272-13-19, 272-13-18, http://nauka-nanrk.kz. social-human.kz

(C) Қазақстан Республикасының Ұлттық ғылым академиясы, 2018

Типографияның мекенжайы: «Аруна» ЖК, Алматы қ., Муратбаева көш., 75. 
Главный редакто $p$

Почетный член НАН РК

T.O. Балыкбаев

Р е дак ци онн а я коллег и я:

докт. экон. Н., проф., академик НАН РК У.Б. Баймуратов; докт. ист. н., проф., академик НАН РК К.М. Байпаков; докт. филос. Н., проф., академик НАН РК Г.Е. Есим; докт. фил. Н., проф., академик НАН РК С.С. Кирабаев; докт. экон. Н., проф., академик НАН РК А.К. Кошанов; докт. экон. Н., проф., академик НАН РК К.Н. Нарибаев (заместитель главного редактора); докт. филос. н., проф., академик НАН РК А.Н. Нысанбаев; докт. юр. Н., проф., академик НАН РК С.Н. Сабикенов; докт. юр. н., проф., академик НАН РК М.К. Сулейменов; докт. экон. Н., проф., академик НАН РК С.С. Сатубалдин; докт. ист. н., проф., академик НАН РК Х.М. Абжанов; докт. ист. н., проф., чл.-корр. НАН РК М.Х. Абусеитова; докт. ист. н., проф., академик НАН РК Б.А. Байтанаев; докт. фил. н., проф., чл.-корр. НАН РК Б.А. Жакып; докт. фиолол. н., проф., академик НАН РК У.К. Калижанов; докт. фил. н., проф., академик НАН РК Д. Камзабекулы; докт. ист. н., проф., академик НАН РК Д.П. Кожамжарова; докт. ист. н., проф., академик НАН РК М.К. Койгельдиев; докт. филол. н., проф., чл.-корр. НАН РК Ш. Курманбайулы; докт. ист. н., проф., чл.корр. НАН РК Ж.К. Таймаганбетов; докт. социол. н., проф., чл.-корр. НАН РК З.К. Шаукенова; д. филол. н., проф., чл.-корр. НАН РК А. Дербисали; доктор политических наук, проф., Бижанов А.К.; доктор ист. наук, проф., Кабульдинов 3.Е.; доктор филол. н., проф., член-корр. НАН РК Қажыбек Е.3.

Р е дак ци онны й с ов е т

академик НАН Республики Молдова Г. Белостечник (Молдова); академик НАН Азербайджанской Республики Н. Велиханлы (Азербайджан); академик НАН Республики Таджикистан Т.Н. Назаров (Таджикистан); академик НАН Республики Молдова А. Рошка (Молдова); академик НАН Республики Молдова Г. Руснак (Молдова); чл.-корр. НАН Азербайджанской Республики Ш. Мурадов (Азербайджан), член-корр. НАН Азербайджанской Республики 3.Сафарова (Азербайджан); д. э. н., проф. В.Н. Василенко (Украина); д.ю.н., проф. В.А. Устименко (Украина)

Известия Национальной академии наук Республики Казахстан. Серия общественных и гуманитарных наук. ISSN 2224-5294

Собственник: РОО «Национальная академия наук Республики Казахстан» (г. Алматы)

Свидетельство о постановке на учет периодического печатного издания в Комитете информации и архивов

Министерства культуры и информации Республики Казахстан № 10894-Ж, выданное 30.04.2010 г.

Периодичность 6 раз в год

Тираж: 500 экземпляров

Адрес редакции: 050010, г. Алматы, ул. Шевченко, 28, ком. 219, 220, тел. 272-13-19, 272-13-18, www:nauka-nanrk.kz / social-human.kz

(C) Национальная академия наук Республики Казахстан, 2018 г.

Адрес типографии: ИП «Аруна», г. Алматы, ул. Муратбаева, 75

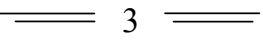


Chief Editor

\section{Honorary member of NAS RK \\ Balykbayev T.O}

Editorial board:

Doctor of economics, prof, academician of NAS RK Baimuratov U.B.; doctor of history, prof, academician of NAS RK Baipakov K.M.; doctor of philosophy, prof, academician of NAS RK Esim G.E.; doctor of philology, prof, academician of NAS RK Kirabayev S.S.; doctor of economics, prof, academician of NAS RK Koshanov A.K.; doctor of economics, prof, academician of NAS RK Naribayev K.N. (deputy editor-in-chief); doctor of philosophy, prof, academician of NAS RK Nyssanbayev A.N.; doctor of law, prof, academician of NAS RK Sabikenov S.N.; doctor of law, prof, academician of NAS RK Suleymenov M.K.; doctor of economy, prof, academician of NAS RK Satybaldin S.S.; doctor of history, prof, academician of NAS RK Abzhanov H.M; doctor of history, prof, corresponding member of NAS RK Abuseitova M.H.; doctor of history, prof, academician of NAS RK Baitanaev B.A.; doctor of philology, prof, corresponding member of NAS RK Zhakyp B.A.; doctor of philology, prof, academician of NAS RK Kalizhanov U.K.; doctor of philology, prof, academician of NAS RK Hamzabekuly D.; doctor of history, prof, academician of NAS RK Kozhamzharova D.P.; doctor of history, prof, academician of NAS RK Koigeldiev M.K.; doctor of philology, prof, corresponding member of NAS RK Kurmanbaiuly Sh.; doctor of history, prof, academician of NAS RK Taimaganbetov J.K.; doctor of sociology, prof, corresponding member of NAS RK Shaukenova Z.K.; doctor of philology, prof, corresponding member of NAS RK Derbisali A.; doctor of political science, prof Bizhanov A.K; doctor of History, prof Kabuldinov Z.E.; doctor of philology, prof, corresponding member of NAS RK Kazhybek E.Z.

\section{Editorial staff:}

Academician NAS Republic of Moldova Belostechnik.G (Moldova); Academician NAS Republic of Azerbaijan Velikhanli N. (Azerbaijan); Academician NAS Republic of Tajikistan Nazarov T.N. (Tajikistan); Academician NAS Republic of Moldova Roshka A. (Moldova) Academician NAS Republic of Moldova Rusnak G. (Moldova); Corresponding member of the NAS Republic of Azerbaijan Muradov Sh. (Azerbaijan); Corresponding member of the NAS Republic of Azerbaijan Safarova Z. (Azerbaijan); Associate professor of Economics Vasilenko V.N. (Ukraine), Associate professor of Law Ustimenko V.A. (Ukraine)

News of the National Academy of Sciences of the Republic of Kazakhstan. Series of Social and Humanities. ISSN 2224-5294

Owner: RPA "National Academy of Sciences of the Republic of Kazakhstan" (Almaty)

The certificate of registration of a periodic printed publication in the Committee of information and archives of the Ministry of culture and information of the Republic of Kazakhstan N 10894-Ж, issued 30.04.2010

Periodicity: 6 times a year

Circulation: 500 copies

Editorial address: 28, Shevchenko str., of. 219, 220, Almaty, 050010, tel. 272-13-19, 272-13-18, www:nauka-nanrk.kz / social-human.kz

(C) National Academy of Sciences of the Republic of Kazakhstan, 2018

Address of printing house: ST "Aruna", 75, Muratbayev str, Almaty 
N E W S

OF THE NATIONAL ACADEMY OF SCIENCES OF THE REPUBLIC OF KAZAKHSTAN

SERIES OF SOCIAL AND HUMAN SCIENCES

ISSN 2224-5294

https://doi.org/10.32014/2018.2224-5294.24

Volume 5, Number 321 (2018), 142 - 146

UDK 657.6

\author{
A.N. Rakaeva ${ }^{1}$, B.A. Zhumataeva ${ }^{1}$, M.K. Uspanbayeva ${ }^{1}$, B.B. Doskalieva ${ }^{2}$ \\ ${ }^{1}$ Eurasian national university of L.N. Gumilev, Astana, Kazakhstan; \\ 2 JSC "Financial Academy", Astana, the Republic of Kazakhstan; \\ e-mail: rakaeva@yandex.ru; doskalievab@mail.ru
}

\title{
LEVEL OF ECOLOGICAL REPORT DEVELOPMENT IN THE ECONOMIC OF KAZAKHSTAN'S COMPANIES
}

\begin{abstract}
The article examines the main issues of the development stage of ecological reporting in Kazakhstan's company's economy. An analysis of the company's indicators of environmental reports has been made according to the local and foreign articles.

Toughening environmental standards, the position of suppliers and consumers, the level of taxation associated with the environment, etc. lead to the emergence of new obligations, new costs that affect the financial condition of enterprises. The analysis of local and foreign publications on the issues of accounting for the company's ecological indicators shows that the existing approaches are contradictory, differ in their goals and basic classification characteristics. Nevertheless, the problems associated with their timely reflection, necessitate the need for an appropriate accounting. To date, the financial statements do not contain enough non-financial information neither information about intangible assets. Ignoring environmental liabilities in accounting and, as a consequence, not including them in reporting is dangerous for many reasons. First of all, shareholders may wish to retain the shares achieved in the price. Secondly, the lack of a certain policy in the field of environmental obligations can lead to the fact that management personnel will not timely draw the attention of senior management to environmental problems. Third, the organization can establish a reputation as irresponsible. And, finally, shareholders can try to bring suits against an organization that does not provide relevant information.
\end{abstract}

If a environmental report is new in Kazakhstan, meanwhile in the world principles of this report developed in a high degree. We will consider the actual environmental costs of Kazakhstan enterprises.

Key words: environmental reporting, the costs of environmental protection, payments.

Strict environmental standards, the status of suppliers and consumers, environmental tax rates, and so on. The emergence of new obligations affects the costs that affect the financial condition of the enterprise. The enterprise should solve in a timely manner incoming problems. In our opinion, an environmental report is a tool for measure and determine the environmental costs.

Environmental accounting is an effective information system on the impact of economic entities on the environment and in case to minimize its impact we there is need to inform the third party. Environmental accounting reports are accounting the system of environmental performance and environmental impact assessment reports, as well as for an accurate and complete depiction of the economic system for environmental change.

The materials and methods used in this article are used for comparisons and analysis, monitoring, evaluation and research. They are the basis methods of analysis of the study of ecological report objects.

Results and discussion. As accounting is a practical science, it requires the clarification of the comparative status of the environmental report in the entire accounting system and its relationship with traditional financial and management accounting systems.

The concept of environmental reporting for Kazakhstani companies remains a new phenomenon annually, but its principles have been advancing for a long time in the world. Many world-renowned companies regularly prepare non-financial reports on sustainable development in environmental reporting. At present, there are no international accounting standards that disclose environmental information in corporate financial statements.

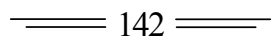


The analysis of the state of the reporting and reporting of the environmental activity of the Kazakh enterprises has shown insufficient level of its organization. Environmental reporting is carried out in organizations regularly, often through samples, statistical reports and expert assessments. Most of the existing environmental costs are not separated into separate accounting and reporting items.

In many enterprises there is a violation of accounting environmental costs. At the same time, it is " dissolves" at the cost that is relevant. Environmental costs of the enterprise are calculated on an unreasonable basis with respect to occupational safety and health or other costs. Therefore, the basis for the development of environmental accounting is prevention of crisis phenomena, which is sociallyeconomically important.

All this creates difficulties for identifying a specific environmental environment of the enterprise, does not contribute to the organization of control over the environmental costs, and does not allow the creation of optimum management decisions in the responsibility centers that affect the final results of financial and economic activities. In Kazakhstan, as in a number of other countries, polluting enterprises do not include the corresponding products (services) for nomenclatures for control and statistics bodies, they report only to general emissions and provide relevant information. In our country, there is no uniform methodology for reporting environmental issues. In this case, the Ministry of Finance of the Republic of Kazakhstan recommends that enterprises be should guided by the general reporting requirements.

When analyzing domestic and foreign publications on the accounting of environmental performance of enterprises, the existing approaches contradict different purposes and differentiated by the main classification characteristics.

Environmental research by foreign researchers considers the industrial enterprises as a set of internal management accounting, financial reporting for external reporting purposes as well as cost-benefit analysis methods. Therefore, K.S. Sayenko is providing its definition natural of economic organization continuously in custody, of ecological liabilities, ecological business operations as an organized system for gathering, writing and summarizing information in physical and money resources of the organization through its chain [1]. Survey of E.V. Ilyicheva "Environmental Impact of Balance Sheet Environmental Accounting Policy" provides identification, assessment, planning and forecasting, monitoring and analysis of environmental costs and environmental obligations, and provides information on collection, registration and summary reporting in the segments as well as the environment protection report. [2]

The concept of ecological account L.P. Lazarev usually combines informational function and environmental management with accountability for natural resources, which, in its turn, defines the collection and analysis of information on the quantity and quality of available natural resources to predict trends in the organization of rational use of natural resources, planning of economic and ecological activities, and the use of nature, current and future changes in environment. [3]

Scottish scientist R. Gray, is highlighting the following elements in the environmental report: Accounting and Auditing, Environmental Management, Environmental Reporting, Sustainable Business Development [4].

In the work of S.M. Shapiguzov, the disclosure of information about the company's nature protection activities will help its owners evaluate the management's activities, provide wide public control, and assist in the formation of a positive image of the enterprise [5].

According to S.M. Bychkova and M.Yu. Egorov the environmental reporting system should contain the following key elements: 1.Accounting policy that includes environmental aspects; 2.Full account of environmental costs (capital and current); 3.Determine the cost of environmental obligations and their accounting; 4.Formation of ecological record [6].

The development of environmental accounting and reporting is being carried out all over the world. International organizations (UNEP, United Nations Conference on Trade and Development (UNCTAD), United Nations Commission on Sustainable Development (CSD), US Environmental Protection Agency (EPA) and others.

Most of the studies in the field of environmental accounting are relevant, but the role of accounting in the solution of environmental problems at the expense of accounting reform in accordance with IFRS in Kazakhstan is changing.

It should be noted that all environmental costs are in Kazakhstan's practice.

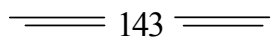


However, the development of environmental accounting requires optimization of environmental costs, adaptation to modern requirements for financial and managerial accounting, especially in the formulation of appropriate costs. There should be a source of information for reporting: primary environmental reporting and statistical reporting; set of shots to the organization; disposal of emissions and waste; documents of the use of natural resources and environmental pollution as well as payments on natural investment.

Analysis of the dynamics of current expenditure for environmental protection will allow them to determine their small growth. The percentage of total environmental expenditure is capital expenditure. (1-picture)

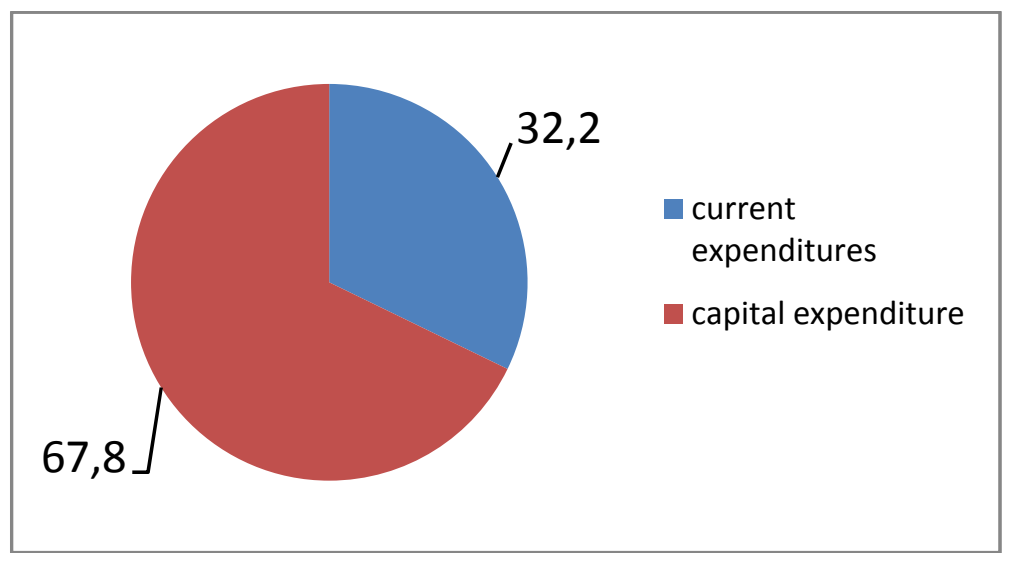

1-picture - composition of ecological costs

Note: made in accordance with information of Statistics Agency of the Republic of Kazakhstan \#37-4/276 dated 02/08/2016 http://stat.gov.kz [7]

As picture 2 shows, the total cost structure is based on a steady process of costs management for wastewater collection and treatment, atmospheric air protection and climate change prevention, waste management. During the analyzed period, the share of costs for protecting and restoring land, groundwater and surface water has decreased.

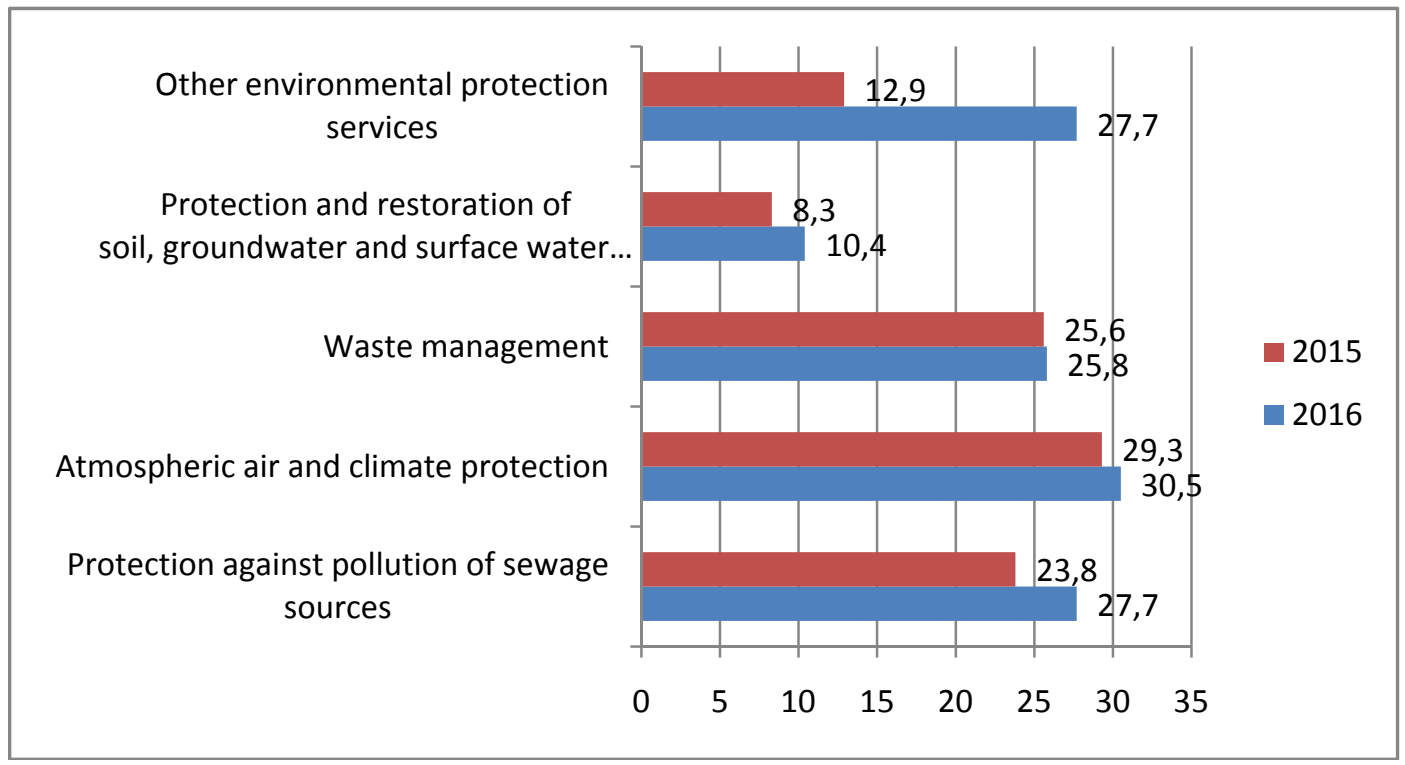

2-picture - Structure of expenditures on environmental protection in the Republic of Kazakhstan

Note: made in accordance with information of Statistics Agency of the Republic of Kazakhstan \#37-4/276 dated 02/08/2016 http://stat.gov.kz [7] 
Thus, in the theory and practice of accounting we solve the issues related to the recognition and evaluation of environmental protection costs.

Without the full and reliable information about natural objects, the environmental protection function is unavailable. However, both the indicators and the accounting systems are not developed, which makes it easy to regulate the relationships between environment and company. Currently, enterprises are responsible for environmental pollution only in the form of payment.

In the current practice, four types of environmental pollution charges are used: 1) emissions (emissions) of pollutants into the environment; 2) for normative distribution of industrial wastes and environment; 3 ) penalties for exceeding standards of emission (emission) of pollutants in the environment; 4) penalties exceeding the standards of wastes generated and consumed in the natural environment.

Current payments, taxes and charges in the field of environmental management and environmental protection are the main sources of the budget of the Republic of Kazakhstan. With their help, the state exercises the owner's rights to natural resources, gets rid of the leasing of natural resources and covers costs and damages due to the increase and protection of these resources.

The experience of the developed countries of the West shows that investments in the production of environmentally-friendly production of energy and material resources, increase of competitiveness of products in the world and domestic markets, increase the number of jobs, etc. through revenue growth. Kazakhstani companies are characterized by a trend toward profit, not taking into account environmental requirements.

Difficulties in linking environmental activities to traditional economic activities at Kazakhstani enterprises result in data on the use of natural resources and environmental protection in the existing accounting system. In this regard, it must be admitted that there is a need for the work of environmental agents in the accounting system. An environmental asset is a resource derived from interactions with the environment and the environment, as well as by producing products, performing works or servicing, as well as generating future economic benefits, as well as reducing environmental and financial risks. Future economic benefits generated in environmental assets can be realized in different ways: saving savings and current costs associated with adverse environmental impacts, improving competitiveness of extracted ecologically clean products and servicing the environment. Availability of ecological assets in enterprises minimizes the risk of an organization's closure, leads to the loss of the firm's level of prices, lower sales, and lower product prices. Ultimately, future economic benefits of environmental assets are the potential cash outflows or their equivalents, as well as the decline in their yield. We are determined by the need to calculate this situation:

- reduction of burden on the environment during the product lifecycle for risk prevention and mitigation;

- reduction of liability for ecological reasons;

- produced goods for licensing for winning and strengthening competitive positions in the market;

- Benefits of the information received on environment protection objects;

- elimination of excessive pollution charges, payment of sick leave sheets for environmental reasons, etc. cost savings.

Conclusion. Thus, the introduction of environmental reporting in production activities requires not only changes in accounting policies and reporting, but also management changes. Kazakhstan enterprises need to know the potential benefits of this decision. The investor's confidence in financial reporting will increase when he makes investment decisions correctly if he / she discovers the company's environmental obligations. If they are able to demonstrate that their products and services are ecologically competitive in their competition, they will have the privilege. 


\section{А.Н. Ракаева ${ }^{1}$, Б.А. Жуматаева ${ }^{1}$, М.К. Успамбаева ${ }^{1}$, Б.Б. Доскалиева ${ }^{2}$ \\ ${ }^{1}$ Евразийский национальный университет им. Л.Н. Гумилева, Астана; \\ ${ }^{2} \mathrm{AO}$ «Финансовая академия». \\ ЭКОЛОГИЧЕСКИЙ УЧЕТ КАК СТУПЕНЬ \\ РАЗВИТИЯ ЭКОНОМИКИ ПРЕДПРИЯТИЯ В КАЗАХСТАНЕ}

Аннотация: В работе раскрываются основые проблемы развития экологического учета в экономики предпритий Казахстана. Проведен анализ отечественных и зарубежных публикаций по вопросам учета экологических показателей предприятия. Понятие экологического учета для казахстанских компаний каждый год остается новым явлением, хотя его принципы давно развиваются во всем мире. Также рассмотренно современное состояние отражение экологических затрат в отчетностях казахстанских предпряитиях.

Ключевые слова: экологический учет, затраты на охраны окружающей среды, платежи.

\section{А.Н. Ракаева ${ }^{1}$, Б.А. Жуматаева ${ }^{1}$, М.К. Успамбаева ${ }^{1}$, Б.Б. Доскалиева ${ }^{2}$ \\ ${ }^{1}$ Л.Н. Гумилев атындағы Еуразия ұлттық университеті, Астана; \\ ${ }^{2}$ Астана қаласы, «Қаржы академиясы» АҚ}

\section{ЭКОЛОГИЯЛЫҚ ЕСЕП ҚАЗАҚСТАНДАҒЫ КӘСІПОРЫН ЭКОНОМИКАСЫНЫН ДАМУ КЕЗЕНІ РЕТІНДЕ}

Түйін. Баяндамада Қазақстан экономикасында экологиялық есепке алудың негізгі проблемалары анықталды. Компанияның экологиялық көрсеткіштерін есепке алу мәселелері бойынша отандық және шетелдік басылымдарды талдау жүргізілді. Қазақстандық компаниялар үшін экологиялық есеп тұжырымдамасы жыл сайын жаңа құбылыс болып қала береді, бірақ оның қағидалары бүкіл әлемде ұзақ уақыт бойы дамыды. Сондай-ақ, қазақстандық кәсіпорындардың есептеріндегі шығындардың ағымдағы жайкүйі қарастырылды.

Түйін сөздер: экологиялық есеп, экологиялық шығындар, төлемдер.

\section{REFERENCES}

[1] Sayenko K.C. Accounting for ecologic costs. - M: Finances and Statistica, 2005, 376 p.

[2] Illyichiv E.V. The cross-section of the financial, financial, economic and eco- logical framework // Financial News, 2009, No. 1.p.66-67.

[3] Lazareva L.P., Milovets V.M. Ecological indicators. // Wologdinskoye Reading. Vladivtok, 2008, 173-178 p.

[4] Gray R. "The Economical science: Today and Tomorrow". - (Economics: yesterday and tomorrow, 1949.

[5] Shapigyzov S.M., Shneidman L.Z. Ecologistical reporyt for businesses / collection: The OOn conference on the development and development M: Finansy and statistica, 1997. - 200 p.

[6] Bychkova S.M. The role and importance of economic and legal affairs in the market economy (C.M. Bychkova, M.Yu. Egorov) // ECONOMICS of commercial and manufacturing enterprises, 2001, No. 9

[7] Committee on Statistics of the Ministry of National Economy of the Republic of Kazakhstan, http://stat.gov.kz

Information about author:

Rakaeva A.N. - Eurasian national university of L.N. Gumilev, Astana, Kazakhstan;

Zhumataeva B.A. - Eurasian national university of L.N. Gumilev, Astana, Kazakhstan;

Uspanbayeva M.K. - Eurasian national university of L.N. Gumilev, Astana, Kazakhstan;

Doskalieva B.B. - ${ }^{2}$ JSC "Financial Academy", Astana, the Republic of Kazakhstan; 


\section{МАЗМҰНЫ}

Алтыбаева С.М., Савындыков Е.С. Көркем мәтін құрылымындағы мифопоэтикалық модельдеу және мәдени код...... 5 Сембиева Л.М., Мажитов Д.М., Карпиикая М.Е., Хамитова Д.М. Экономиканы жаңғырту жағдайындағы ЕАЭО елдерінің монетарлық жүесінін өзгеруі .....

Құлсариева А.Т., Султанова М.Э., Шайгозова Ж.Н. Фольклор және сәйкестілік: Қазақстанның қазіргі заманғы

мәдениетіндегі тарих, жады және аңыз шығармашылығы ........................................................................................... 19

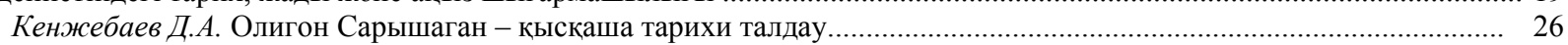

АбдулинаГ.А., БазарбаевА.Г. Ұйымдардағы адам ресурстарын басқарудың заманауи тұжырымдамалары................ 33

Авыбаев А.Н., Адибаева А.К. Геноцид туралы БҰҰ Конвенциясының қатысушы мемлекеттердің қылмыстық

заңнамаларындағы имплементациялық тетіктері: жалпы салыстырмалы талдау............................................................ 39

Ахметжанов Б., Тәжібекова К.Б., Шаметова А.А. Қазақстан көлік өнеркәсіптің дамуын талдау............................. 44

Аюпова 3.К., Құсайынов Д.Ө. Тәуелсіздік жағдайындағы қазақстан республикасының конституциялық-құқықтық

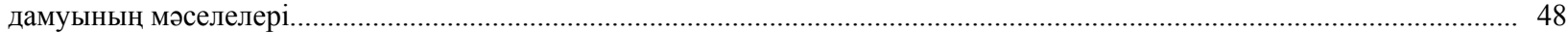

Нурпеисова А.А., Рей И.Ю., Бижанов Д.Т., Тлеужанова Д.А. Инновациялық өндірісді жасаудың процесін

бақылауының негізгі элементтері

Гиздатов Г.Г. Қазақстандық дискурсының құрылымы психолингвистиякалық зерттеу .

Ищанова Р.К. Мемлекеттік шығындарды басқару - мемлекеттің қаржылық тұрақтылығын қамтамасыз ету.............. 64

Мадышева А.М. Бикенова А.С., Елеусиз Л.Т. Білім саласындағы туристік қызметтер............................................. 68

Ескалиева А. Ж., Баймуханова М.Т., Ахмурзина Д.О. Әлеуметтік сала адам капиталының сапасын қолдаудың

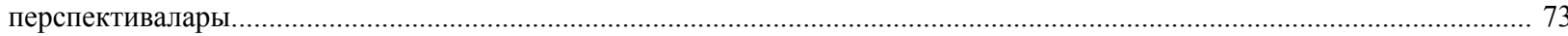

Мархаева Б.А., Козбахова Д.Л. Жауапкершілік орталық және трансферттік баға белгілеу............................................ 79

Сабирова Р.К., Утепкалиева К.М., Кабаков С.Б. Қазақстандағы ауыл шаруашылығы экономикасының

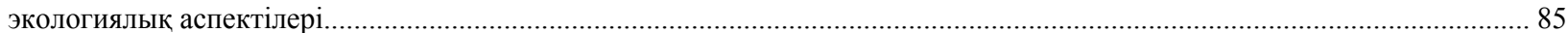

Тлесова Э., Хойч А., Кураш Н. Қазақстан республикасының ғылыми инновациялық потенциясы және оның

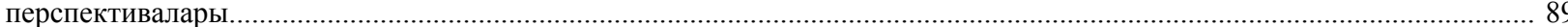

Хамитхан Н. Қазақстандағы банктік қызметтердің сапасын жақсарту жағдайында банкаралык басекелестік............ 95

Шалдарбеков Қ.Б., Муханова Г.С., Нурмухамбетова 3.С. Аймақтарды дамыту бағдарламаларын жүзеге асырудағы жобалық басқаруды қолданудың шетелдік тәжірибесі

КаратаеваА.М., Бердиярова Ж.С. Мемлекеттік қызметшінің әдептік мәдениеті және құқықтық мәдениеті

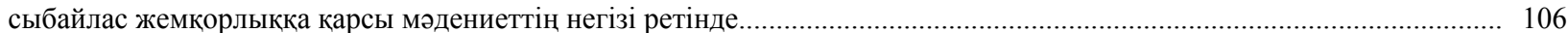

Алдабергенова А.А. Абсурд әдебиетін аударудың лингвомәдени аспектілері ................................................... 113

Стукач В. Ф., Байдалинова А. С., Сандыбаева Б. А. Қазақстанның қаржылық қауіпсіздігі......................................... 119

Баймаханова Д.М., Оспанова Д.А. Конституциялық-құқықтық сана - конституционализмнің маңызды

компоненті ретінде және оның адам құқықтары мәселелерін шешудегі рөлі................................................................. 126

Имангожина 3.А. Сланцевая революция: глобальный тренд на мировом энергетическом рынке............................. 137

Ракаева А.Н., Жуматаева Б.А., Успамбаева М.К., Доскалиева Б.Б. Экологиялық есеп қазақстандағы кәсіпорын экономикасының даму кезеңі ретінде

Нуржанова Г.И. Экономиканың аграрлық секторындағы еңбек әлеуетіне демографиялық фактордың әсері............ 147

Оспанова Д.А., Баймаханова Д.М. Қазақстан Республикасының кибер кеңістігін дамыту жағдайында мемлекеттік қызметтерді цифрландыруда әкімшілік-құқықтық қамтамасыз ету ................................................................................... 152

Pblсnекова М.О., Тлесова Э.Б., Хаитбаева Ф.К. Қазақстандағы тұрғын үй-коммуналдық шаруашылық қызметін

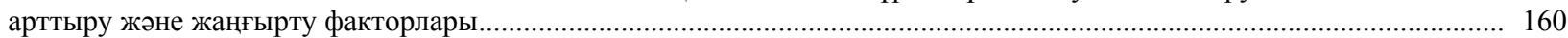

Султанова Г. Т. Аграрлық сектордың экспорттық әлеуетін дамытуға бағытталған үрдістер мен басымдықтар........ 166 


\section{СОДЕРЖАНИЕ}

Алтыбаева С.М., Сагындыков Е.С. Культурный код и мифопоэтическое моделирование в структуре художественного текста.

Сембиева Л.М., Мажитов Д.М., Карпиикая М.Е., Хамитова Д.М. Трансформация монетарной системы стран

ЕАЭС в условиях модернизации экономики.............................................................................................................

Кулсариева А.T., Султанова М.Э., Шайгозова Ж.Н. Фольклор и идентичность: история, память и мифотворчество

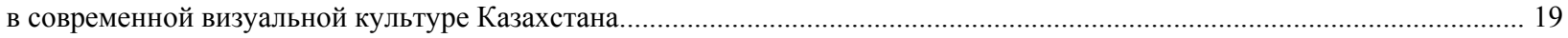

Кенжебаев Д.А. Полигон Сарышаган - краткий исторический анализ................................................................ 26

Абдулина Г.А., БазарбаевА.Г. Современные концепции управления человеческми ресурсами в организациях........... 33

Агыбаев А.Н., Адибаева А.К. Имплементационные механизмы Конвенции ООН о геноциде в уголовных

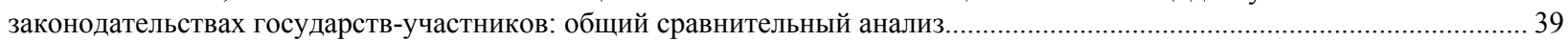

Ахметжанов Б., Тажибекова К.Б., Шаметова А.А. Анализ развития угольной промышленности Казахстана........... 44

Аюпова 3.К., Кусаинов Д.У.Проблемы конституционно-правового развития республики Казахстан в условиях

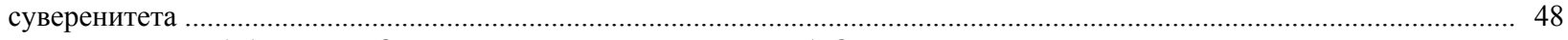

Нурпеисова А.А., Рей И.Ю., Бижанов Д.Т., Тлеужанова Д.А. Основные элементы управления процессом создания

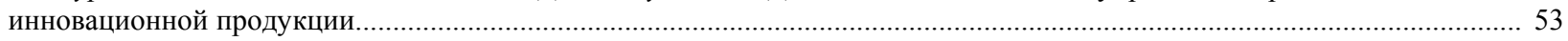

Гиздатов Г.Г. Психолингвистическое исследование концептов казахстанского дискурса...................................... 57

Ищанова Р.К. Управление государственными расходами - как обеспечение финансовой устойчивости государства. 64

Мадымева А.М. Бикенова А.С., Елеусиз Л.Т. Туристские услуги в сфере образования........................................... 68

Ескалиева А. Ж., Баймуханова М.Т., Ахмурзина Д.О. Перспективы усиления качества человеческого капитала

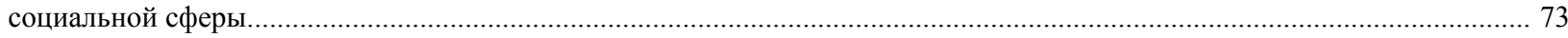

Мархаева Б.А., Козбахова Д.Л. Центр ответственности и трансфертное ценообразование..................................... 79

Сабирова Р.К., Утепкалиева К.М., Кабаков С.Б. Экологические аспекты экономики сельского хозяйства

в Казахстане........................................... 85

Тлесова Э., Хойч А., Кураш Н. Научно-инновационный потенциал республики Казкастан и его перспективы............ 89

Хамитхан Н. Межбанковская конкуренция в условиях повышения качества банковских услуг в Казахстане.............. 95

Шалдарбеков К.Б., Муханова Г.С., Нурмухамбетова 3.С. Зарубежный опыт применения проектного управления

при реализации программ развития регионов

Каратаева А.М., Бердиярова Ж.С. Этическая культура и правовая культура государственных служащих

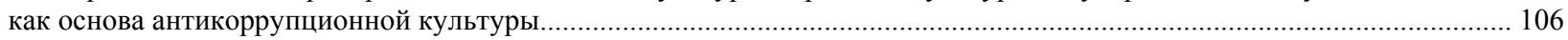

Алдабергенова А.А. Лингвокультурологические аспекты перевода литературы абсурда.......................................... 113

Стукач В. Ф., Байдалинова А. С., Сандыбаева Б. А. Казахстанская финансовая безопасность.................................... 119

Баймаханова Д.М., Оспанова Д.А. Конституционно-правовое сознание как важный компонент конституционализма

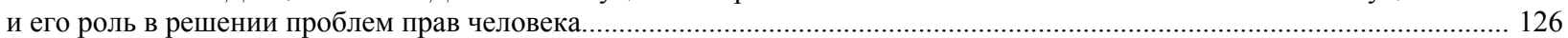

Имангожина 3.A. Сланцевая революция: глобальный тренд на мировом энергетическом рынке............................. 137

Ракаева А.Н., Жуматаева Б.А., Успамбаева М.К., Доскалиева Б.Б. Экологический учет как ступень развития

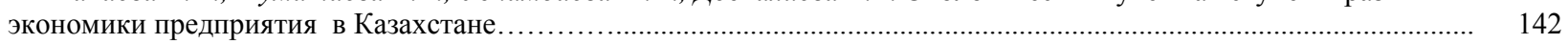

Нуржанова Г.И. Влияние демографического фактора на трудовой потенциал аграрного сектора экономики............ 147

Оспанова Д.А., Баймаханова Д.М. Административно-правовое обеспечение цифровизации государственных услуг

в условиях развития кибер пронстранства республики Казахстан..

Pыспекова М.О., Тлесова Э.Б., Хаитбаева Ф.К. Факторы инновационной модернизации и совершенствования

деятельности жилищно-коммунального хозяйства в Казахстане.

160

Султанова Г. Т. Тенденции и приоритеты развития экспортного потенциала аграрного сектора................................ 166 


\section{CONTENTS}

Altybayeva S.M., Sagyndykov E.S. Cultural code and myth poetic modeling in the structure of the artistic text..................... 5 Sembiyeva L.M., Mazhitov D.M., Karpitskaya M.E., Khamitova D.M. Transformation of the monetary system of the eurasian economic UNION countries in the conditions of modernization of the economy......

Kulsarieva A.T., Sultanova M.E., Shaigozova Zh.N. Folklore and identity: history, memory and myth-making in the modern

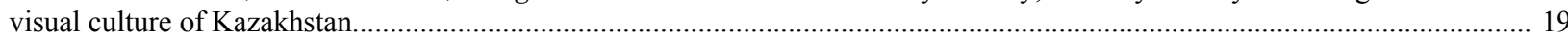

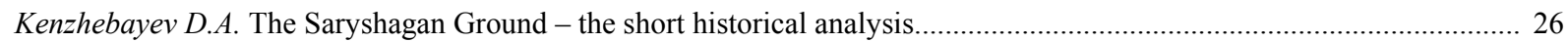

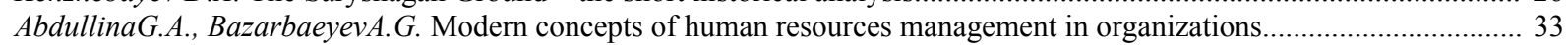

Agybayev A.N., Adibayeva A.K. Implementing mechanisms of the UN Convention on genocide in the criminal legislation

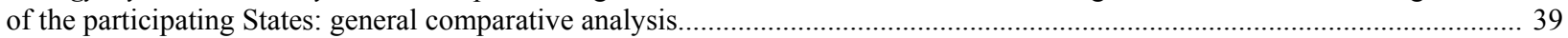

Akhmetzhanov B., Tazhibekova K.B, Shametova A.A. Analysis of development of the coal industry of Kazakhstan.............. 44 Ayupova Z.K., Kussainov D.U. Problems of constitutional and legal development of the republic of kazakhstan in the conditions of sovereignty......

Nurpeisova A.A., Rey I.Yu., Bizhanov D.T., Tleuzhanova D.A. Main elements of managing the process of creating innovation production.

Gizdatov G.G. Psycholinguistic study of the concepts of Kazakhstar

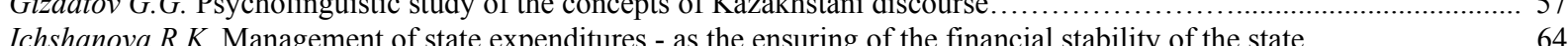

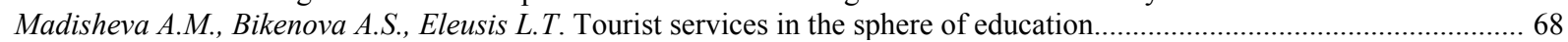

Eskalieva A. Zh., Baymukhanova M.T., Ahmurzina D.O. Perspectives of strengthening the quality of the human capital

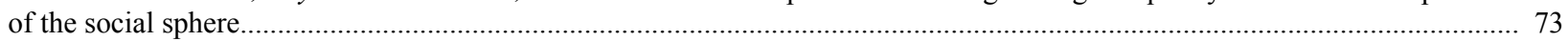

Markhayeva B.A., Kozbakhova D.L. A responsibility center and transfer pricing ................................................. 79

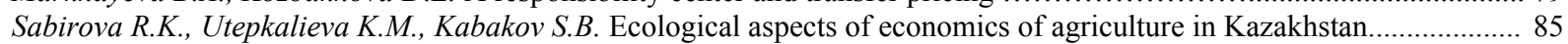

Tlessova E., Khoich A., Kurash N. Scientific innovation potential of the republic of Kazkahstan and its perspectives........ 89

Hamitkhan $N$. Interbank competition in conditions of improving the quality of banking services in Kazakhstan.................. 95

Shaldarbekov K., Mukhanova G., Nurmukhambetova Z. International practices in project management in implementing

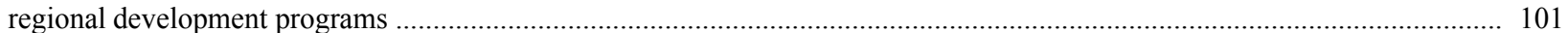

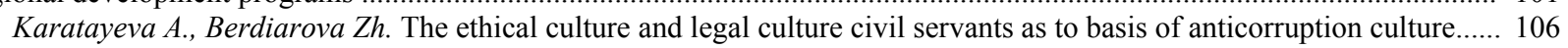

Aldabergenova A.A. Linguocultural aspects of translation of absurd literature.............................................................. 113

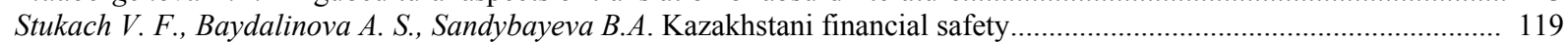

Baimakhanova D.M., Ospanova D.A. Constitutional and legal consciousness as an important component of constitutionalism

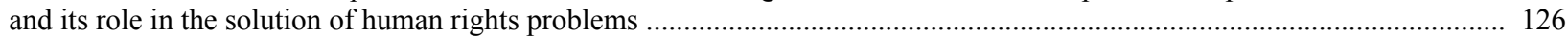

Imangozhina Z.A. Shale gas revolution: global trend in the world energy market..................................................... 137

Rakaeva A.N., Zhumataeva B.A., Uspanbayeva M.K., B.B.Doskalieva. Level of ecological report development in the economic of Kazakhstan's companies.

Nurzhanova G.I. Impact of demographic factors on labor potential of economy's agricultural sector

Ospanova D.A., Baimakhanova D.M. Administrative and legal support of digitalization of public services in the context of the development of cyber space in the republic of Kazakhstan....

Ryspekova M.O., Tlessova E.B., Khaitbayeva F. Factors of innovative modernization and improvement of activity

of housing and communal services in Kazakhstan.

Sultanova G. T. Trends and priorities for the development of export potential of the agrarian sector. 


\title{
PUBLICATION ETHICS AND PUBLICATION MALPRACTICE IN THE JOURNALS OF THE NATIONAL ACADEMY OF SCIENCES OF THE REPUBLIC OF KAZAKHSTAN
}

For information on Ethics in publishing and Ethical guidelines for journal publication see http://www.elsevier.com/publishingethics and http://www.elsevier.com/journal-authors/ethics.

Submission of an article to the National Academy of Sciences of the Republic of Kazakhstan implies that the work described has not been published previously (except in the form of an abstract or as part of a published lecture or academic thesis or as an electronic preprint, see http://www.elsevier.com/postingpolicy), that it is not under consideration for publication elsewhere, that its publication is approved by all authors and tacitly or explicitly by the responsible authorities where the work was carried out, and that, if accepted, it will not be published elsewhere in the same form, in English or in any other language, including electronically without the written consent of the copyrightholder. In particular, translations into English of papers already published in another language are not accepted.

No other forms of scientific misconduct are allowed, such as plagiarism, falsification, fraudulent data, incorrect interpretation of other works, incorrect citations, etc. The National Academy of Sciences of the Republic of Kazakhstan follows the Code of Conduct of the Committee on Publication Ethics (COPE), and follows the COPE Flowcharts for Resolving Cases of Suspected Misconduct (http://publicationethics.org/files/u2/New Code.pdf). To verify originality, your article may be checked by the originality detection service Cross Check http://www.elsevier.com/editors/plagdetect.

The authors are obliged to participate in peer review process and be ready to provide corrections, clarifications, retractions and apologies when needed. All authors of a paper should have significantly contributed to the research.

The reviewers should provide objective judgments and should point out relevant published works which are not yet cited. Reviewed articles should be treated confidentially. The reviewers will be chosen in such a way that there is no conflict of interests with respect to the research, the authors and/or the research funders.

The editors have complete responsibility and authority to reject or accept a paper, and they will only accept a paper when reasonably certain. They will preserve anonymity of reviewers and promote publication of corrections, clarifications, retractions and apologies when needed. The acceptance of a paper automatically implies the copyright transfer to the National Academy of sciences of the Republic of Kazakhstan.

The Editorial Board of the National Academy of sciences of the Republic of Kazakhstan will monitor and safeguard publishing ethics.

Правила оформления статьи для публикации в журнале смотреть на сайте:

$$
\begin{gathered}
\text { www:nauka-nanrk.kz } \\
\text { social-human.kz }
\end{gathered}
$$

\author{
Редакторы М.С. Ахметова, Т.А. Апендиев, Д.С. Аленов \\ Верстка на компьютере А.М. Кульгинбаевой \\ Подписано в печать 10.10.2018 \\ Формат 60x881/8. Бумага офсетная. Печать - ризограф. \\ 11,6 п.л. Тираж 500. Заказ 5.
}

